\title{
Research on Optimization of Training Program for Master's Degree in Pedagogy with Social Need Orientation
}

\author{
Ya-hui $\mathrm{Wu}^{*}$ \\ School of Educational Science \\ Northeast Petroleum University \\ Daqing, China
}

\begin{abstract}
At present, the training of high quality applied talents in pedagogy should be oriented by the needs of society. From the perspective of social need orientation, there are some problems in the training program of master's degree in pedagogy, such as unclear training objectives, inflexible schooling system, imperfect curriculum, imperfect tutor system, insufficient practice links and low differentiation of assessment methods. Taking the social need as the orientation, this paper proposes to optimize the training program of master degree in pedagogy from the following six aspects: clear training objectives, flexible revision of the school system, improvement of the curriculum, establishment of "double tutors" system, construction of practice bases and improvement of assessment methods.
\end{abstract}

Keywords-Training program; Master's degree in pedagogy; Social need orientation; Optimization

\section{INTRODUCTION}

Graduate education in pedagogy is the main way to cultivate high-level applied talents in pedagogy; it is the main basis and programmatic document for training master students with professional degrees. Optimizing the training program for master's degree in pedagogy is conducive to cultivating students' practical ability to master rich knowledge and apply knowledge.

\section{The Social NeEd Orientation OF MAster's Degree TRAINING PROGRAM IN PEDAGOGY}

"The 13th five-year plan for degree and graduate education development" points out: "actively develop graduate education of master's professional degrees, and establish the development mechanism of graduate education of master's professional degrees oriented by career needs" ${ }^{\prime 1]}$. Since 2009, China began to fully implement the recruitment of professional degree for postgraduates, which started late and developed at a fast speed. The main goal is to cultivate the application ability and practical ability of postgraduates. Engels said: "when society has a need, it pushes it forward more than 10 universities." The national establishment of master's degree in pedagogy is to meet the needs of personal comprehensive quality improvement and meet the needs of diversified society for new talents in pedagogy. In recent years, it has become a recognized fact that it is difficult for pedagogy graduate

Fund projects: Northeast petroleum university graduate education innovation engineering project education and teaching reform project (JYCX_JG20_2018); Northeast petroleum university graduate education innovation engineering project graduate innovative research project (JYCX_CX20_2018); students to find a job, largely because the society's need for pedagogy graduate students has changed, and the single talent of theoretical knowledge can no longer meet the rapid development of economy and society. Guided by social needs and optimize the professional degree in pedagogy of postgraduate training program, the colleges and universities "supply" and "social" requirements "organic link, training there are both theoretical knowledge and practical ability of pedagogy talents for universities for construction" much starker choices-and graver consequences-in planning and delivery of new talent "the only way for constructing high level university.

III. Current Situation of Training Programs For MASTER's Degree STUdents IN PEDAGOGY With SOCIAL

\section{NEED ORIENTATION}

\section{A. Unclear Training Objectives}

The unclear orientation of talent training program not only leads to the convergence of talent types, but also leads to the waste of educational resources. Professional degree in pedagogy of postgraduate in market demand, but according to the school teachers strength and advantages of disciplines in colleges and universities set up, professional degree in pedagogy of postgraduate training target is mostly used academic graduate training program, not separate the two different talents training target zone, training target positioning is not clear, did not reflect practical, not out of the school envelops, too wide a target cannot be targeted to develop social needed talents.

\section{B. Inflexible Schooling System}

The length of schooling and the length of study are rigid and fixed, which do not conform to the needs of social development and the law of talent growth for master students majoring in pedagogy. The length of pedagogy postgraduate in a few universities is fixed at 3 years. More and more colleges and universities implement the flexible academic system, but in the implementation process there are deviations, still implement the unified academic system, can't give full play to the individuality and creativity of students.

\section{Imperfect Curriculum}

The curriculum setting of the training program mainly includes four aspects: course content, course structure, course teaching method, and course assessment. Master's degree in 
pedagogy focuses on the training of practical talents. The curriculum content of colleges and universities is relatively fixed and out of line with the actual social needs. The curriculum content is not updated in a timely manner. The unreasonable curriculum structure is reflected in the fact that multiple public compulsory courses are more important than elective courses, while theoretical courses are more important than practical courses. Therefore, students have fewer opportunities to choose courses and fewer opportunities to practice. The teaching method of the course is more lecturing, less discussion, heuristic, and exploration. The course assessment system is not perfect, and teachers of all courses do not have unified standards for the proportion of students' normal grades and final grades in the assessment. Some postgraduate course examination questions are too rigid to examine students' ability to apply what they have learned.

\section{Imperfect Tutor System}

In the process of out-of-school practice for postgraduate students majoring in pedagogy, the tutor's guidance is not enough, and the out-of-school practice is not communicated with the tutor timely and concretely. Tutors in the university usually have academic expertise in a certain research direction or research field, but they are not necessarily proficient in all aspects of practice and do not necessarily have a complete practical knowledge structure. In the process of guiding students' practice, it is easy to find that the guidance is not in place.

\section{E. Insufficient Practice Links}

The lack of emphasis on the practical part of the training program for master's degree in pedagogy is mainly reflected in the insufficient investment in students' practical funds and the small proportion of practical courses. Practice teaching funds investment is small, students need to pay their own expenses to participate in the practice, for the family financial difficulties of students pressure, leading to students can't fully be committed to learning practice, is not conducive to the quality of professional degree master training. Practical courses are the key to the training of professional master degree students, and the emphasis on theoretical courses over practical teaching courses is the main factor restricting the optimization of the training program for professional master degree students.

\section{F. Low Differentiation of Assessment Methods}

"Although in professional degree graduate training program that teachers can use exam, course thesis, homework, class discussion, research reports, and other forms of assessment method" ${ }^{[2]}$, in order to more convenient, but the teachers often will only in the form of regular assignments and class paper appraised, but this way is more suitable for academic degree in pedagogy of postgraduate examination of basic requirements. Most people ignore the training objectives of master's degree in pedagogy and fail to consider the difference between academic and professional master's students.

\section{Optimization Path of Training PROgRAm FOR Master's Degree In Pedagogy With Social NeEd ORIENTATION}

\section{A. Clear Training Objectives}

Different universities and disciplines have different training objectives for postgraduates with professional degrees. Only the training objectives that reflect the characteristics of the specialty and the advantages of the industry can cultivate talents with characteristics required by society. The ministry of education of human resources and social security ministry about in-depth opinions to push forward the reform of professional degree graduate training model explicitly request: "professional degree graduate training goal is to master a certain professions related theory knowledge, has the strong ability to solve practical problems, to undertake professional technical or management work, have good professional quality of high-level talents"'[3]. Each college professional degree in pedagogy of postgraduate training goals should be agreed jointly by the university teacher and mentor, surrounding the social need for pedagogy professional personnel training target, according to the university's own subject advantages and industry advantages, "to guide the reasonable orientation, to overcome the homogeneity tendency to form their own educational philosophy and style, have the characteristics at different levels, different areas, to create first-class" ${ }^{14]}$.

\section{B. Flexible Revision of the School System}

Our professional degree graduate student cultivation system for 2-3 years, degree courses to learn general requirements in previous years, graduate student grade two learning into the practice base for practice, professional practice time not less than half a year, based on the social needs of the professional degree in pedagogy practice of postgraduate time according to the fixed number of year of the college study and extend or shorten the students learning situation. The flexible length of schooling and the length of study are adopted in some universities in China, which can't only stimulate students' learning enthusiasm, but also promote the maximum play of educational resources.

\section{Improvement of the Curriculum}

"In order to improve the quality of courses, colleges and universities should constantly improve the curriculum settings according to the needs of social development" ${ }^{[5]}$.To improve the curriculum system of professional master's degree postgraduate training program, we need to break the traditional curriculum settings and retain professional basic courses. The content of professional courses can be changed according to social needs and hot issues of the times, and increase the types of professional elective courses so that students can flourish according to their own needs. Hobbies have more opportunities to choose, flexible credit settings, students can cross-disciplinary choice of professional elective courses, assessment results qualified before they can get credit. Increase the comprehensive curriculum; improve students' ability to use knowledge comprehensively. "The training program should reasonably set up the curriculum system and training links, and increase the proportion of practical courses." ${ }^{[6]}$. Professional practical courses are indispensable for Postgraduates of professional degree. Students must train practical teaching 
skills and application knowledge through professional practice courses.

\section{Establishment of "Double Tutors" System}

Most of the graduate tutors in Colleges and universities are highly educated, and they are in Colleges and universities from study to work, lacking the practical ability of social production. However, the purpose of master's degree in pedagogy is to cultivate applied talents, which is scarce in the social market. Universities can through School-enterprise cooperation to "employ senior professional and technical personnel with rich practical experience as part-time tutors" ${ }^{17]}$. Each master's degree in pedagogy should have two tutors, one in-school tutor and one out-of-school tutor. The two tutors should guide the formulation of an individual training plan. If there is only one in-school tutor, the cultivation of master's degree in pedagogy is easy to lose its characteristics and become an academic postgraduate. The first half of student's study in colleges and universities is mainly guided by in-school tutors, while the second half of students' practical study is mainly guided by out-of-school tutors. Through the "double tutor" system, students can make full use of the professional knowledge they have learned in practice, so as to make full use of the knowledge and improve their professional level.

\section{E. Construction of Practice Bases}

The postgraduate practice mainly includes social practice, academic reports, teaching practice and so on. Some of the postgraduates with master's degree in pedagogy have no purpose to practice in enterprises, some just go through the stage, and some will take part in the work without technical gold content in enterprises and do not get skills training. Constructing a practice base and strengthening the relationship between enterprises and universities is the only way to change the shortage of practice of master's degree postgraduates majoring in pedagogy. The postgraduate practice course is mostly carried out through practice base, which is an important place to improve student's professional skills. Students are allowed to participate in practice purposefully with problems. Out-of-school tutors guide, supervise and evaluate students' practical activities in practice base. "In order to improve student's professional skills, it is necessary to formulate targeted solutions to various problems in the process of students' practice" $^{[8]}$.

\section{F. Improvement of Assessment Methods}

Consciously separate academic master of education from the professional master of education for examination and evaluation, enhance the pertinence of evaluation, properly increase the assessment of basic skills and practical links of master of education professional degree, and examine students by both in-school and out-of-school tutors. Graduation thesis is not the only way to assess professional degree postgraduates. The most important thing is to improve the assessment methods according to social needs; graduation thesis of professional degree postgraduates can make diversified requirements. According to the different requirements of professional dissertations, the assessment criteria are refined from the aspects of social needs and improving student's practical application ability and the application orientation of master's dissertations for pedagogy is strengthened.

\section{SUMMARY}

Optimizing the training program of master's degree in pedagogy plays a fundamental role in ensuring and improving the quality of master's degree in pedagogy. Faced with the new tasks and missions of the new era, we must optimize the training program of master's degree postgraduates in pedagogy in time according to the changes of social needs, constantly improve the quality of master's degree postgraduates in pedagogy, and serve the needs of personal, national and social development.

\section{REFERENCE}

[1] Ministry of Education, Academic Degree Committee of the State Council."The 13th five-year plan for degree and graduate education development"[EB/OL].(2017-01-21)[2019-05-02].http://www.moe.edu.c n/jyb_xwfb/s5147/201701/t20170122_295473.html.(In Chinese)

[2] Xiong Ye,Yuan Fengqin.A Comparative Study on the Evaluation of Master's Courses of Professional and Academic Types: Taking Preschool Education and Preschool Education as Examples [J].Journal of Hunan Mass Media Vocational and Technical College,2016(5):108-111.(In Chinese)

[3] Ministry of Education, Ministry of Human Resources and Social Security.Suggestions on Deeply Promoting the Reform of Professional Degree Postgraduate Training

Model[EB/OL].(2013-11-04)[2018-07-09].

http://old.moe.gov.cn/publicfiles/business/htmlfiles/moe/moe 823/2013 11/159870.html.(In Chinese)

[4] Ministry of Education of the People's Republic of China."Outline of the National Medium-and Long-Term Education Reform and Development Plan(2010-2020)"[EB/OL].(2010-07-29)[2019-05-01].http://old.moe.gov .cn/publicfiles/business/htmlfiles/moe/info_list/201407/xxgk_171904.ht ml.(In Chinese)

[5] Ma Yun-kuo, Wu Ya-hui.Strategies to Improve the Quality of Academic Graduate Education[J]. Educational Exploration,2019 (2):74-78.(In Chinese)

[6] Gao Yue.Analysis of the Current Situation of Course Setting in Sports Training Field of Full-time Sports Master Degree in Shandong Province[D].Jinan: Shandong Normal University,2014.(In Chinese)

[7] He Yi-tuan. The role of school-enterprise joint training base in the formulation of postgraduate training programs [J]. Educational and teaching forum,2015 (50):205-206.(In Chinese)

[8] Liang Xian-yan, Zhu Jing.Research on Optimization of undergraduate talent training program guided by social needs [J].Education and teaching research,2014(2):57-60.(In Chinese) 